\title{
Regulation of ovarian steroidogenesis in vitro by gonadotropin in common carp Cyprinus carpio: interaction between calcium- and adenylate cyclase-dependent pathways and involvement of ERK signaling cascade
}

\author{
Sudipta Paul, Sourav Kundu, Kousik Pramanick, Arun Bandyopadhyay ${ }^{1}$ \\ and Dilip Mukherjee \\ Endocrinology Laboratory, Department of Zoology, University of Kalyani, Kalyani 741235, West Bengal, India \\ ${ }^{1}$ Molecular Endocrinology Laboratory, Indian Institute of Chemical Biology, 4 Raja S C Mullick Road, Kolkata 700032, West Bengal, India \\ (Correspondence should be addressed to D Mukherjee; Email: dilipmukher@ rediffmail.com)
}

\begin{abstract}
Multiple signal transduction pathways mediating gonadotropin-induced testosterone and 17ß-estradiol $\left(\mathrm{E}_{2}\right)$ production were identified in carp ovarian theca and granulosa cells in short-term co-incubation. Inhibitors of voltage-sensitive calcium channels (VSCCs) and calmodulin attenuated human chorionic gonadotropin (HCG)-induced steroid production, whereas modulators of adenylate cyclase and protein kinase A (PKA) increased their production, indicating that both calcium- and PKA-dependent pathways are involved in the regulation of gonadotropin-induced steroidogenesis in carp ovary. Interactions between these two pathways are evident from the positive effect of elevated intracellular calcium on HCG-induced steroid production and the reduction of forskolin (FK)- and dibutyryl cAMP (dbcAMP)-induced steroidogenesis by inhibitors of VSCCs and calmodulin. In this study, we found the involvement of a third signaling pathway, a mitogen-activated protein kinase (MAP kinase), in the regulation of gonadal steroidogenesis in this fish. An antagonist of mitogen-activated protein kinase kinases 1/2 (MEK1/2; also known as MAP2K1/MAP2K2) markedly attenuated HCG-induced steroid production. Cells treated with HCG stimulated MEK1/2-dependent phosphorylation of extracellular signal-regulated protein kinases 1/2 (ERKs1/2) in a concentration and time-dependent manner. Moreover, ERK1/2 activation in cells was mimicked by FK and dbcAMP suggesting that ERK1/2 transduce signal downstream of PKA in HCG-induced ovarian steroidogenesis. Evidence for presence of cross talk between calcium-dependent pathways and this MAP kinase cascade has been shown by demonstrating the inhibitory effects of verapamil and calmodulin on ERK1/2 activation after HCG stimulation. Our results suggest that activation of ERK1/2 by HCG as well as other agents may be a key mechanism for the modulation of gonadotropin-induced steroidogenesis in carp ovary.
\end{abstract}

Journal of Molecular Endocrinology (2010) 45, 207-218

\section{Introduction}

The stimulation of gonadal steroidogenesis by pituitary gonadotropins is mediated by various intracellular signaling mechanisms. In ovarian steroidogenic cells, gonadotropins bind to specific membrane G-proteincoupled receptors (GPCRs) and lead to the activation of multiple signal transduction pathways, including the adenylate cyclase-/cAMP-dependent protein kinase A (PKA) signaling pathway and calcium-/calmodulindependent pathways (see review in Leung \& Steele (1992) and Van Der Kraak \& Wade (1994)). Cross talk among these signal transduction systems has been well documented in many cell types and in response to a variety of receptor agonists (Rasmussen 1981, Bygrave \& Roberts 1995, Richards 2001). Moreover, several adenylate cyclase isoenzymes are known to be up- or downregulated by calcium (Guillou et al. 1999). Available information also reported for involvement of mitogen-activated protein kinase (MAP kinase) signaling in the regulation of ovarian steroidogenesis in mammals (Amsterdam et al. 2003). The extracellular signal-regulated protein kinases (ERKs) group of MAP kinase includes three kinases (P-42 ERK2, P-44 ERK1, and P-46 ERK1b), which are phosphorylated by the mitogen-activated protein kinase kinases, MEK1 and MEK2 (also known as MAP2K1 and MAP2K2; Seger \& Krebs 1995, Lewis et al. 1997). In mammalian granulosa cells, ERK1/2 is activated in response to gonadotropins and is important in the regulation of gonadotropininduced ovarian steroidogenesis (Moore et al. 2001, Dewi et al. 2002, Amsterdam et al. 2003, Su et al. 2006, Woods \& Johnson 2007). Moreover, occurrence of a cross talk between either adenylate cyclase- or calcium-dependent signaling pathway and MAP kinase cascade has also been demonstrated (Richards 2001; reviewed in Agell et al. (2002)).

DOI: 10.1677/JME-10-0061 Online version via http://www.endocrinology-journals.org 
Previous studies have demonstrated the involvement of adenylate cyclase- and calcium-dependent pathways in mediating the effects of gonadotropins on ovarian steroidogenesis in teleosts (Van Der Kraak \& Wade 1994, Benninghoff \& Thomas 2005, 2006a). However, an interaction between these pathways in the regulation of ovarian steroidogenesis in fish is not well understood. A recent study showed that testosterone synthesis in Atlantic croaker ovarian follicles induced by activators of adenylate cyclase and PKA is sensitive to antagonists of voltage-sensitive calcium channels (VSCCs), calmodulin, and calcium-/calmodulin-dependent protein kinases (CaMKs), indicating the occurrence of a cross talk between adenylate cyclase- and calcium-dependent pathways (Benninghoff \& Thomas 2006a). Although available information indicates the involvement of ERKs in the regulation of gonadotropin-induced steroidogenesis in mammalian granulosa cells, the precise role of this protein kinase in mediating hormone-induced steroidogenesis in fish ovary is unclear. Recently, Benninghoff \& Thomas (2006b) suggested an involvement of MAP kinase signaling cascade in gonadotropininduced steroidogenesis in Atlantic croaker ovarian follicles. Interestingly, they have indicated the occurrence of a cross talk only between adenylate cyclase and MAP kinase pathways in these processes.

Therefore, the primary objective of this study was to investigate whether gonadotropin induces activation of ERK1/2 in mediating gonadotropin-induced steroid production in common carp (Cyprinus carpio) ovarian theca and granulosa cells in short-term co-incubation. We also tried to investigate the possible interactions between adenylate cyclase-/calcium-dependent pathway and MAPKs pathways in gonadotropin-induced steroid production in carp ovarian follicles.

\section{Materials and methods}

\section{Chemicals}

Dibutyryl cAMP (dbcAMP), forskolin (FK), verapamil, calcium ionophore A23187, calmodulin antagonist W-5, dimethylsulfoxide (DMSO), percol, BCS, DMEM/ nutrient mixture F-12 Ham, collagenase type-I, and nitrobluetetrazolium/5-bromo-4-chloro-3-indoylphosphate were purchased from Sigma Chemical. Human chorionic gonadotropin (HCG) was a gift from National Hormone and Pituitary Program (Torrence, CA, USA). Adenylate cyclase inhibitor, SQ22536 (RBI, Natick, MA, USA), was a gift from Dr Sib Sankar Roy, Molecular Endocrinology Laboratory, Indian Institute of Chemical Biology, 4 Raja S C Mullick Road, Kolkata, West Bengal, India. MEK inhibitor PD98059, mouse monoclonal antiphospho ERK1/2 antibody P-ERK, and the secondary antibody goat anti-mouse
$\mathrm{IgG}_{2 \alpha}$ were purchased from Santa Cruz Biotechnology (Santa Cruz, CA, USA). Mouse monoclonal P-ERK (P-E-4) antibody was recommended for detection of ERK1 phosphorylation at Tyr-204 and correspondently ERK2 phosphorylation of multiple species. $\left[{ }^{3} \mathrm{H}\right]$ testosterone (specific activity $95 \cdot 0 \mathrm{Ci} / \mathrm{mmol}$ ) and $\left[{ }^{3} \mathrm{H}\right] 17 \beta$-estradiol $\left(\mathrm{E}_{2}\right.$; specific activity $\left.75.0 \mathrm{Ci} / \mathrm{mmol}\right)$ were purchased from Amersham International Plc. Testosterone and $\mathrm{E}_{2}$ antibodies were gifts from Prof. Gordon Niswender, Colorodo State University, Fort Collins, CO, USA. Verapamil and FK stock solutions were prepared in ethanol and stock solutions of W-5, PD98059, and A23187 were prepared in DMSO so that final concentration of the solvents in the incubation media was $<0 \cdot 1 \%$. All other chemicals used were of analytical grade.

\section{Animals and tissue collection}

Adult C. carpio (300-400 g body weight), collected from a local fish farm in the month of November, were maintained in running tap water in laboratory concrete tanks (300 1 capacity) at $23 \pm 1{ }^{\circ} \mathrm{C}$. They were fed with commercial fish food (Shalimar Fish Food; Bird and Fish Food Manufacturer, Mumbai, India). During the month of November in the plains of West Bengal, India, ovary of common carp comprises mostly postvitellogenic follicles $(0.5-0.7 \mathrm{~mm}$ diameter $)$ with oocytes containing centrally located germinal vesicle and lipid droplets in the cytoplasm were found to initiate coalescence. Follicular stages were determined by striping out few follicles through ovipore followed by examination under microscope after fixing them in clearing solution of acetic acid-ethanol-formalin (1:6:3 v/v) for $12 \mathrm{~h}$. Follicles came out through ovipore after stripping if the fish were in postvitellogenic stage. Fish after screening were deeply anesthetized with MS222 and killed by decapitation at $0800 \mathrm{~h}$ in the morning. Ovaries were removed and placed in ice-cold Idler's medium containing streptomycin $(100 \mu \mathrm{g} / \mathrm{ml})$ and penicillin $(100 \mathrm{IU} / \mathrm{ml})$ adjusted to $\mathrm{pH} 7 \cdot 4$ (Mukherjee et al. 2006), and postvitellogenic stage of the follicles was confirmed after fixing them in clearing solution followed by examination under microscope. Total number of fish examined for this study was 250 .

\section{Tissue preparation}

Ovaries were dissected into small pieces in ice-cold Idler's medium and oocytes with follicle layers were separated by repeated pipetting and collected in fresh medium. Postvitellogenic follicles were separated from previtellogenic $(0 \cdot 2-0 \cdot 3 \mathrm{~mm}$ diameter $)$ and vitellogenic $(0 \cdot 3-0 \cdot 4 \mathrm{~mm}$ diameter $)$ follicles by sieving them through stainless steel wire mesh (i.d. $0.5 \mathrm{~mm}$ ). Follicles thus obtained were initially placed in $50 \mathrm{ml}$ 
sterile glass beaker for $2 \mathrm{~h}$ that contained $5.0 \mathrm{ml}$ medium. This $2 \mathrm{~h}$ preincubation was required to waive the surgical shock (Paul et al. 2008).

Detailed methods for isolation of theca and granulosa cells from ovarian follicles have been described in our previous article (Paul et al. 2010). In brief, ovarian follicles were digested in $0.1 \%$ collagenase type-I for $30 \mathrm{~min}$ in a $25 \mathrm{ml}$ glass beaker containing calcium-magnesium-free Idler's medium with continual gentle mixing on a rotating shaker. Theca and granulosa cells were separated independently from the ovarian follicles. They were then separated from other cell types by layering on a single-density percol layer adopting the procedure described by Benninghoff \& Thomas $(2006 a)$. The final pellet was re-suspended in $1.0 \mathrm{ml}$ culture media and cell density was determined by hemocytometer count. Cell viability, which was $>90 \%$, was ascertained by Trypan blue exclusion method.

\section{Incubation of common carp theca and granulosa cells}

Before each experiment, theca and granulosa cells were mixed and preincubated for $6 \mathrm{~h}$ in a 24-well culture plate in DMEM supplemented with 0.2\% BCS-DMEM, streptomycin $(100 \mu \mathrm{g} / \mathrm{ml})$, and penicillin $(100 \mathrm{IU} / \mathrm{ml})$. The initial density of theca and granulosa cells in the incubation was $0 \cdot 9 \times 10^{5}$ and $2 \cdot 1 \times 10^{5}$ cells per well $(500 \mu \mathrm{l})$ respectively. After $6 \mathrm{~h}$, BCS-DMEM was replaced by serum-free DMEM and incubated in a metabolic shaker bath at $23 \pm 1{ }^{\circ} \mathrm{C}$ for different time intervals in a 24-well culture plate containing effectors and inhibitors. Cell incubations were visually inspected periodically during the experiments and finally at the end of the incubations to ensure that hormone treatment did not cause any observable change in cell density or morphology. At the end of each incubation, medium was aspirated, centrifuged $(3000 \mathrm{~g})$ for $5 \mathrm{~min}$, and the supernatant was stored at $-20^{\circ} \mathrm{C}$ for steroid assay.

\section{Determination of ERK1/2 phosphorylation}

For determination of ERK1/2 phosphorylation, theca and granulosa cell mixtures were preincubated in DMEM for $6 \mathrm{~h}$ followed by $2 \mathrm{~h}$ incubation in SF-DMEM. SF-DMEM medium was replaced twice to reduce basal ERK1/2 phosphorylation levels. Finally, the cells with SF-DMEM media were incubated for varying times containing (described in 'Results' section) various stimulators and inhibitors. After incubations, media were removed; the cells were rinsed with PBS and then lysed with $500 \mu \mathrm{l}$ lysis buffer. Details of determination of ERK1/2 phosphorylation have been described in our previous article (Paul et al. 2009). Briefly, at the end of incubation, cells were washed with fresh medium, pooled from duplicate wells, and then lysed with $100 \mu \mathrm{l}$ ice-cold lysis buffer. Cell lysates were centrifuged at $12000 \mathrm{~g}$ for $5 \mathrm{~min}$ at $4{ }^{\circ} \mathrm{C}$ and supernatant was stored at $-20^{\circ} \mathrm{C}$ until further use. For western blot analysis, supernatant was sonicated for $5 \mathrm{~s}$ on ice and protein content was determined according to the method described by Lowry et al. (1951). An equal volume of protein $(20 \mu \mathrm{g}$ total protein) was electrophoresed through a $10 \%$ SDS-PAGE and transferred to polyvinylidenefluoride membrane (Fermentas Inc. Life Sciences, Glen Burnie, MD, USA). Membranes were blocked for $1 \mathrm{~h}$ in 5\% blocking solution (Tris-buffered saline with $0.1 \%$ Tween-20 and 5\% non-fat milk) followed by incubation with primary antibody for overnight at $4{ }^{\circ} \mathrm{C}$. Mouse monoclonal anti-phospho ERK1/2 antibody P-ERK (P-E-4) validated earlier for use with C. carpio ovarian follicles (Paul et al. 2009) was used at 1:2000 dilutions. Bound primary antibody was visualized using corresponding secondary antibody (goat anti-mouse IgG (1:2000 dilutions)), which was tagged with alkaline phosphatase and was developed with nitrobluetetrazolium/5-bromo-4-chloro-3-indoylphosphate.

\section{Statistical analysis}

Data obtained from three replicate incubations of theca and granulosa cells isolated from single donor fish showed a similar tendency and therefore a mean of all the three data was considered as one experiment. All data were expressed as mean \pm s.E.M. of five such experiments taking cells from five donor fish or otherwise mentioned in figure legends. After the test for normality and homogeneity, the significance of treatment effects was determined by one-way ANOVA within and across different effectors. Individual comparisons between treatments were made by adopting Bonferroni's multiple comparison tests using SPSS (Chicago, IL, USA). The level of significance chosen was $P<0 \cdot 05$.

\section{Results}

\section{Effects of modulators of adenylate cyclase and PKA on steroid production}

Follicle cells, after $6 \mathrm{~h}$ co-incubation in BSA-DMEM, were treated for $16 \mathrm{~h}$ in SF-DMEM with increasing concentrations of HCG $(0,25,50,100$, or $200 \mathrm{ng} / \mathrm{ml})$, the adenylate cyclase activator FK $(0,0 \cdot 1,1 \cdot 0$, or $10 \mu \mathrm{M})$, or the membrane permeable cAMP analog, dbcAMP $(0,0 \cdot 1,1 \cdot 0$, or $10 \mathrm{mM})$, and the steroid content in the media was examined. Results shown in Table 1 demonstrate that treatment of HCG, FK, and dbcAMP significantly increased testosterone and $\mathrm{E}_{2}$ production by co-incubated theca and granulosa cells almost in a 
Table 1 Effects of modulators of adenylate cyclase (forskolin) and protein kinase A (PKA; dibutyryl cAMP (dbcAMP)) on steroid production and inhibitors of adenylate cyclase (SQ22536), voltage-sensitive calcium channels (VSCCs; verapamil) and calmodulin (W-5) on human chorionic gonadotropin (HCG)-stimulated steroid production. Theca and granulosa cells of Cyprinus carpio were incubated in SF-DMEM containing various concentrations of modulators and/ or inhibitors for $16 \mathrm{~h}$ at $23 \pm 1{ }^{\circ} \mathrm{C}$. Cells were pre-incubated for $1 \mathrm{~h}$ in the presence of inhibitors. Each value represents \pm S.E.M. of five experiments, comprising three replicate incubations of follicle cells obtained from single donor fish

\begin{tabular}{|c|c|c|c|}
\hline Stimulators/inhibitors & Doses & Testosterone (pg/ml) & $17 \beta$-estradiol $(\mathrm{pg} / \mathrm{ml})$ \\
\hline Control & - & $127 \pm 13 \cdot 6$ & $130 \pm 15 \cdot 4$ \\
\hline \multirow[t]{4}{*}{ HCG (ng/ml) } & 25 & $348 \pm 17 \cdot 2^{*}$ & $470 \pm 32 \cdot 5^{\star}$ \\
\hline & 50 & $480 \pm 24 \cdot 3^{*}$ & $570 \pm 37 \cdot 9^{*}$ \\
\hline & 100 & $740 \pm 33 \cdot 01^{\star, a}$ & $880 \pm 78 \cdot 3^{\star, a}$ \\
\hline & 200 & $762 \pm 35 \cdot 02^{*}$ & $885 \pm 69 \cdot 9^{*}$ \\
\hline \multirow[t]{3}{*}{ Forskolin $(\mu \mathrm{M})$} & $0 \cdot 1$ & $462 \pm 35 \cdot 4^{*}$ & $580 \pm 46 \cdot 1^{*}$ \\
\hline & $1 \cdot 0$ & $670 \pm 43 \cdot 2^{*}$ & $770 \pm 65 \cdot 9^{*}$ \\
\hline & 10 & $740 \pm 53 \cdot 2^{*}$ & $840 \pm 63 \cdot 5^{\star}$ \\
\hline \multirow[t]{3}{*}{ dbcAMP (mM) } & $0 \cdot 1$ & $426 \pm 44 \cdot 9^{\star}$ & $520 \pm 48 \cdot 02^{*}$ \\
\hline & $1 \cdot 0$ & $615 \pm 76 \cdot 8^{*}$ & $735 \pm 72 \cdot 49^{*}$ \\
\hline & 10 & $660 \pm 75 \cdot 9^{*}$ & $800 \pm 76 \cdot 44^{*}$ \\
\hline \multirow[t]{3}{*}{ HCG (100 ng/ml) + SQ22536 (mM) } & $0 \cdot 1$ & $655 \pm 60 \cdot 9$ & $725 \pm 69 \cdot 4$ \\
\hline & 0.5 & $345 \pm 31 \cdot 0^{b}$ & $440 \pm 43 \cdot 3^{b}$ \\
\hline & $1 \cdot 0$ & $222 \pm 26 \cdot 9^{b}$ & $240 \pm 31 \cdot 8^{b}$ \\
\hline \multirow[t]{3}{*}{ HCG $(100 \mathrm{ng} / \mathrm{ml})+$ verapamil $(\mu \mathrm{M})$} & $0 \cdot 1$ & $540 \pm 48 \cdot 6^{b}$ & $607 \pm 57 \cdot 5^{\mathrm{b}}$ \\
\hline & $1 \cdot 0$ & $240 \pm 25 \cdot 1^{b}$ & $250 \pm 31 \cdot 4^{b}$ \\
\hline & $2 \cdot 0$ & $180 \pm 18 \cdot 8^{b}$ & $210 \pm 29 \cdot 5^{b}$ \\
\hline \multirow[t]{5}{*}{ HCG (100 ng/ml) +W-5 ( $\mu \mathrm{M})$} & $0 \cdot 1$ & $630 \pm 54 \cdot 9$ & $700 \pm 69 \cdot 5$ \\
\hline & $0 \cdot 2$ & $505 \pm 43 \cdot 3^{b}$ & $580 \pm 46 \cdot 3^{b}$ \\
\hline & $1 \cdot 0$ & $370 \pm 35 \cdot 6^{b}$ & $370 \pm 54 \cdot 3^{b}$ \\
\hline & $2 \cdot 0$ & $240 \pm 30 \cdot 8^{b}$ & $240 \pm 29 \cdot 9^{b}$ \\
\hline & 10 & $215 \pm 31 \cdot 6^{b}$ & $210 \pm 29 \cdot 5^{b}$ \\
\hline
\end{tabular}

${ }^{\star} P<0.05$ versus without HCG, FK or dbcAMP; ${ }^{a, b}$ means with different letters differ significantly from each other $(P<0.05)$.

concentration-dependent manner compared with their respective control values $(P<0 \cdot 05)$. The optimal effective doses of HCG, FK, and dbcAMP for both the steroid productions were $100 \mathrm{ng} / \mathrm{ml}, 1 \mu \mathrm{M}$, and $1 \mathrm{mM}$ respectively. The minimal tried concentrations at which they were able to induce steroid productions were $25 \mathrm{ng} / \mathrm{ml}, 0 \cdot 1 \mu \mathrm{M}$, and $0 \cdot 1 \mathrm{mM}$ respectively.

\section{Effects of inhibitors of adenylate cyclase, VSCCs, and calmodulin on HCG-stimulated steroid production}

Follicle cells, after $6 \mathrm{~h}$ co-incubation in BSA-DMEM, were treated for $16 \mathrm{~h}$ in SF-DMEM with increasing concentrations of inhibitors of adenylate cyclase, SQ22536 $(0,0 \cdot 1,0 \cdot 5$, or $1 \cdot 0 \mathrm{mM})$; VSCCs, verapamil $(0,0 \cdot 1,1 \cdot 0$, or $2 \cdot 0 \mu \mathrm{M})$; or calmodulin, W-5 $(0,0 \cdot 1,0 \cdot 2$, $1 \cdot 0,2 \cdot 0$, or $10 \cdot 0 \mu \mathrm{M})$, and $\mathrm{HCG}$-stimulated steroid production was examined. It appears from Table 1 that SQ22536, verapamil, and W-5 at their increasing concentrations attenuated HCG-stimulated testosterone and $\mathrm{E}_{2}$ production gradually and significantly $(P<0 \cdot 05)$ after $16 \mathrm{~h}$ of incubation. The concentrations of SQ22536, verapamil, and $\mathrm{W}-5$ at which maximum inhibition recorded were $1 \mathrm{mM}, 2 \mu \mathrm{M}$, and $10 \mu \mathrm{M}$ respectively (Table 1 ).

\section{Effects of inhibitors of VSCCs and calmodulin on FK- and dbcAMP-stimulated steroid productions}

Follicle cells, after $6 \mathrm{~h}$ co-incubation in BSA-DMEM, were treated for $16 \mathrm{~h}$ in SF-DMEM with either no treatment (control) or $1.0 \mu \mathrm{M}$ FK or $1.0 \mathrm{mM}$ dbcAMP to stimulate testosterone and $\mathrm{E}_{2}$ production. Each agonist was tested with and without one of the two inhibitors: $2 \cdot 0 \mu \mathrm{M}$ verapamil or $10 \mu \mathrm{M} \mathrm{W}-5$. Testosterone and $\mathrm{E}_{2}$ production by co-incubated cells induced by the treatment with FK or dbcAMP was significantly attenuated when co-treated with $2 \cdot 0 \mu \mathrm{M}$ verapamil $(P<0 \cdot 05$; Fig. 1A). The calmodulin inhibitor $\mathrm{W}-5$ at a concentration of $10 \mu \mathrm{M}$ also significantly inhibited FKand dbcAMP-induced testosterone and $\mathrm{E}_{2}$ production $(P<0 \cdot 05$; Fig. 1B $)$.

\section{Effects of calcium ionophore A23187 on HCG-stimulated steroid production}

Follicle cells, after $6 \mathrm{~h}$ co-incubation in BSA-DMEM, were treated for $16 \mathrm{~h}$ in SF-DMEM with either increasing concentrations of calcium ionophore A23187 alone (control) or HCG $(50 \mathrm{ng} / \mathrm{ml}$ ) plus increasing concentrations of A23187, and steroid production was estimated. From Fig. 2A and B, it appears that A23187 alone over a dose range of $0,0 \cdot 1$, 

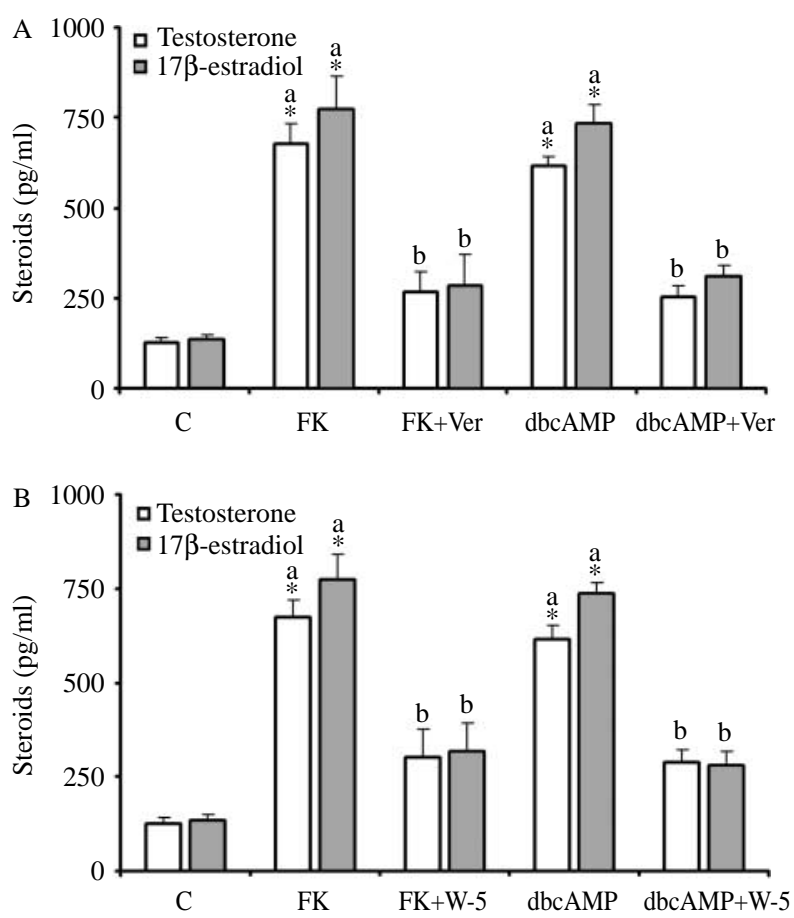

Figure 1 Effects of inhibitors of VSCCs and calmodulin on forskolin- and dbcAMP-stimulated steroid productions by co-incubated theca and granulosa cells ( $A$ and $B$ ). Mean testosterone and $17 \beta$-estradiol production of cells incubated with either no treatment (control, C), 1.0 $\mu \mathrm{M}$ forskolin (FK), or $1.0 \mathrm{mM}$ dbcAMP, each agonist with and without $2 \mu \mathrm{M}$ verapamil (Ver) or $10 \mu \mathrm{M} \mathrm{W}-5$ is shown. Each value represents \pm S.E.M. of five experiments, comprises three replicate incubations of theca-granulosa cells obtained from single donor fish. Asterisk denotes values significantly $(P<0.05)$ different from those shown for without modulators (control). ${ }^{a, b}$ Means with different letters differ significantly from each other $(P<0.05)$.

$0 \cdot 2,0 \cdot 6,1 \cdot 0$, or $2 \cdot 0 \mu \mathrm{M}$ had a stimulatory effect on basal testosterone and $\mathrm{E}_{2}$ production and showed significant stimulation at higher concentrations $(P<0 \cdot 05)$. HCG-stimulated testosterone and $\mathrm{E}_{2}$ production was gradually and significantly increased $(P<0 \cdot 05)$ by $\mathrm{A} 23187$ at increasing concentrations with a maximal at $1.0 \mu \mathrm{M}$ (Fig. $2 \mathrm{~A}$ and $\mathrm{B}$ ).

\section{Effects of inhibitor of MEK1/2 on HCG-stimulated steroid production}

A role for MAPK-activated signaling in HCG-stimulated testosterone and $\mathrm{E}_{2}$ production by co-incubating theca and granulosa cells with HCG and MEK1/2 PD98059 was shown. For this, following $6 \mathrm{~h}$ co-incubation in BSA-DMEM, theca and granulosa cells were preincubated for $1 \cdot 0 \mathrm{~h}$ with increasing doses of PD98059 $(0 \cdot 1$, $1 \cdot 0$, and $5 \cdot 0 \mu \mathrm{M})$ followed by incubation with HCG $(100 \mathrm{ng} / \mathrm{ml})$ for further $16 \mathrm{~h}$, and steroid contents in the media were estimated. Figure $3 \mathrm{~A}$ and B shows that
PD98059 at increasing concentrations gradually and significantly $(P<0 \cdot 05)$ inhibited testosterone and $\mathrm{E}_{2}$ production $(75 \%)$ induced by HCG. At high concentration of PD98059 $(5 \mu \mathrm{M})$, HCG-induced testosterone and $\mathrm{E}_{2}$ production was not significantly different from their basal levels.

\section{Effect of HCG on ERK1/2 phosphorylation and effect of inhibitor of MEK1/2}

After $6 \mathrm{~h}$ incubation in BSA-DMEM and $2 \mathrm{~h}$ in SF-DMEM, media were replaced with fresh SF-DMEM and the cells were treated with increasing concentrations of HCG $(0,10,25,50$, or $100 \mathrm{ng} / \mathrm{ml})$ for $120 \mathrm{~min}$ or for $0,15,30,60$, and 120 min with HCG $(100 \mathrm{ng} / \mathrm{ml})$ or PD98059 $(0,0 \cdot 1$, or $1 \cdot 0 \mu \mathrm{M})$. Immunoblot analysis of the cell lysate demonstrates that treatment of cells with increasing concentrations of HCG for 120 min induced a dose-dependent increase in the levels of phosphorylated ERK1/2 (Fig. 4A). Follicle cells treated with HCG for different times showed increasing levels of phosphorylated ERK1/2, the strongest response to HCG occurred between 60 and $120 \mathrm{~min}$ (Fig. 4B). The stimulatory effect of HCG on phosphorylated ERK1/2 was not attributed to increased ERK protein levels, as total ERK1/2 protein
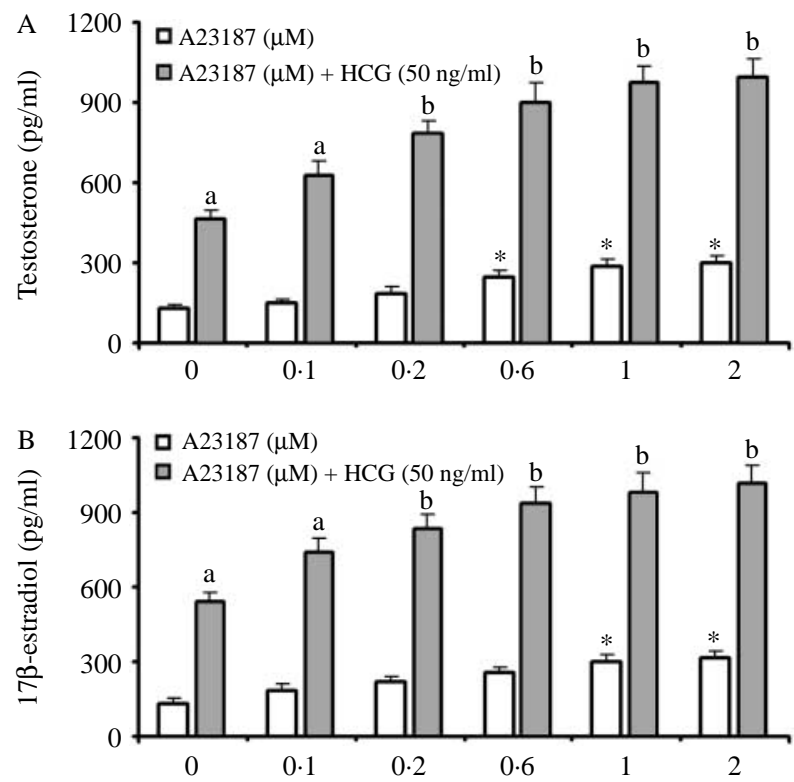

Figure 2 Effects of calcium ionophore A23187 on HCG-stimulated steroid production by co-incubated theca and granulosa cells of common carp (A and B). Cells were incubated in $500 \mu \mathrm{l}$ of serumfree DMEM for $16 \mathrm{~h}$ at $23 \pm 1{ }^{\circ} \mathrm{C}$ with ionophore $\mathrm{A} 23187$ alone at different concentrations or with HCG $(50 \mathrm{ng} / \mathrm{ml})$. Each value represents \pm S.E.M. of five experiments, comprises three replicate incubations of theca-granulosa cells obtained from single donor fish. Asterisk denotes values significantly $(P<0.05)$ different from those shown for without hormone or A23187 (0). ${ }^{a, b}$ Means with different letters differ significantly from each other $(P<0.05)$. 

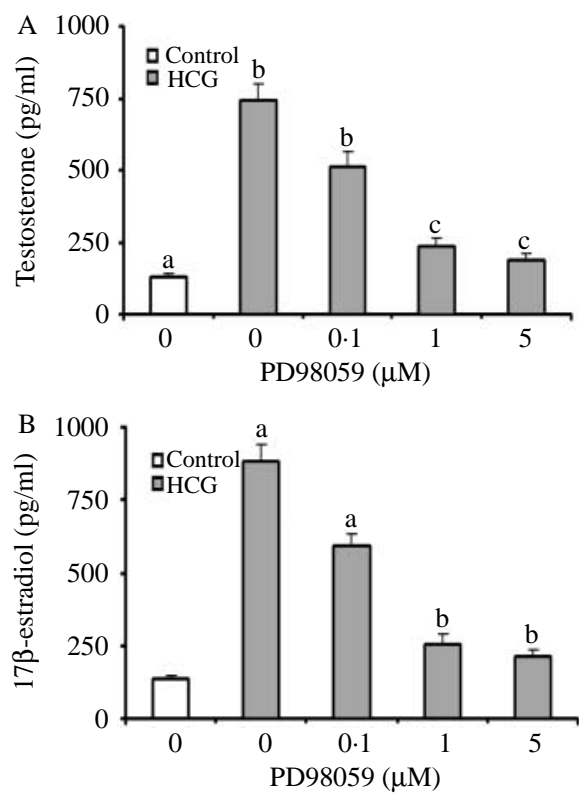

Figure 3 Effects of inhibitors of MEK $1 / 2$ on HCG-stimulated steroid production by co-incubated theca and granulosa cells (A and B). Cells were incubated in $500 \mu \mathrm{l}$ of serum-free DMEM for $16 \mathrm{~h}$ at $23 \pm 1^{\circ} \mathrm{C}$ containing HCG $(100 \mathrm{ng} / \mathrm{ml})$ and increasing concentrations of PD98059. Each value represents \pm S.E.M. of five experiments and comprises three replicate incubations of theca-granulosa cells obtained from single donor fish. ${ }^{\mathrm{a}, \mathrm{b}}$ Means with different letters differ significantly from each other $(P<0.05)$.

was unaffected by incubation time and HCG treatment (Fig. 4A-C, lower panel). Follicle cells treated with HCG $(100 \mathrm{ng} / \mathrm{ml})$ for 60 and $120 \mathrm{~min}$ in the presence of increasing concentrations of PD98059 $(0,0 \cdot 1$, or $1 \cdot 0 \mu \mathrm{M})$ blocked ERK1/2 phosphorylation almost in a concentration-dependent manner (Fig. 4C).

\section{Effect of MEK inhibitor on FK- and dbcAMP-stimulated steroid productions}

Follicle cells, after $6 \mathrm{~h}$ incubation in BSA-DMEM and $2 \mathrm{~h}$ incubation in SF-DMEM, were preincubated for $1 \mathrm{~h}$ with $1.0 \mu \mathrm{M}$ of PD98059 followed by incubation with HCG $(100 \mathrm{ng} / \mathrm{ml})$, FK $(1 \cdot 0 \mu \mathrm{M})$, or dbcAMP $(1.0 \mathrm{mM})$ for $16 \mathrm{~h}$, and steroid contents in the media were estimated. It appears from Fig. 5A and B that PD98059 significantly $(P<0 \cdot 05)$ attenuated the steroidogenic response to HCG, FK, and dbcAMP by 68,62 , and $60 \%$ respectively.

\section{Effect of modulators of adenylate cyclase and PKA on ERK1/2 phosphorylation and effect of MEK inhibitor}

Follicle cells, after $6 \mathrm{~h}$ incubation in BSA-DMEM and $2 \mathrm{~h}$ incubation in SF-DMEM, were treated for $1 \mathrm{~h}$ with PD98059 $(1.0 \mu \mathrm{M})$ followed by incubation with HCG $(100 \mathrm{ng} / \mathrm{ml})$ or FK $(1 \cdot 0 \mu \mathrm{M})$ or dbcAMP
(1.0 mM) for $120 \mathrm{~min}$, and ERK1/2 phosphorylation was examined. It appears from Fig. 6 that treatment with HCG or dbcAMP or FK for 120 min increased the levels of ERK1/2 phosphorylation in co-incubated theca and granulosa cell lysate of common carp. The MEK inhibitor PD98059 at concentration of $1.0 \mu \mathrm{M}$ reduced basal levels of active ERK1/2 and blocked HCG-, dbcAMP-, and FK-induced increases in ERK1/2 phosphorylation (Fig. 6).

\section{Effect of inhibitors of VSCCs and calmodulin on HCG-induced ERK1/2 phosphorylation}

In a separate experiment we tested the ability of VSCCs blocker, verapamil, and calmodulin inhibitor, W-5, to modulate the HCG-stimulated and basal ERK1/2 activity in co-incubated theca and granulosa cells of common carp. For this, following $6 \mathrm{~h}$ incubation in BSA-DMEM and $2 \mathrm{~h}$ in SF-DMEM, cells were treated for $1 \mathrm{~h}$ with $1.0 \mu \mathrm{M}$ PD98059 followed by incubation with $2 \mu \mathrm{M}$ verapamil, $10 \mu \mathrm{M} \mathrm{W}-5$ with or without HCG $(100 \mathrm{ng} / \mathrm{ml})$ for $120 \mathrm{~min}$, and ERK1/2 phosphorylation was determined. It appears from Fig. 7 that ERK1/2 phosphorylation induced by HCG was sufficiently blocked by the treatment with verapamil $(2 \cdot 0 \mu \mathrm{M})$ and $\mathrm{W}-5(10 \mu \mathrm{M})$.

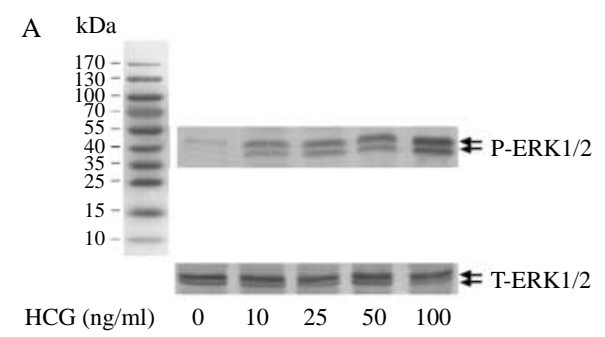

B
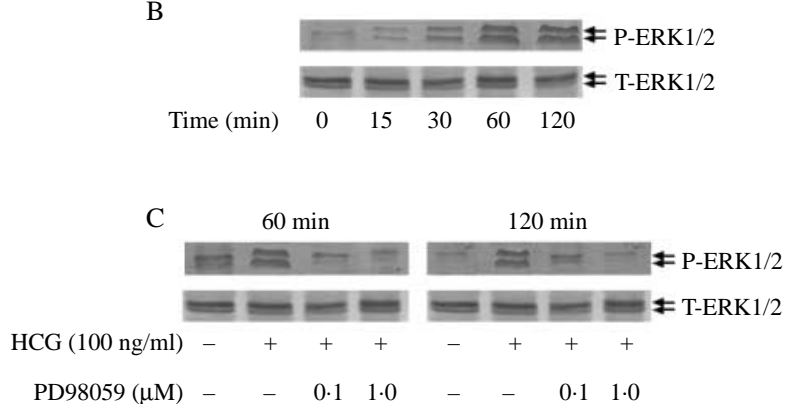

Figure 4 Concentration-, time-, and MEK1/2-dependent activations of ERK $1 / 2$ by HCG in co-incubated theca and granulosa cells. Immunoblot analyses of phosphorylated ERK1/2 (P-ERK1/2) and total ERK1/2 (T-ERK1/2) in cells incubated with increasing concentrations of HCG for $120 \mathrm{~min}(A)$, with $100 \mathrm{ng} / \mathrm{ml}$ HCG for $15-120$ min (B), or with $100 \mathrm{ng} / \mathrm{ml} \mathrm{HCG}$ and increasing concentrations of PD98059 for $60 \mathrm{~min}(\mathrm{C})$. Mobilities of molecular mass standard are given in $\mathrm{kDa}$ on the left $(A)$. Immunoblot analyses were performed at least three times with nearly identical results. 

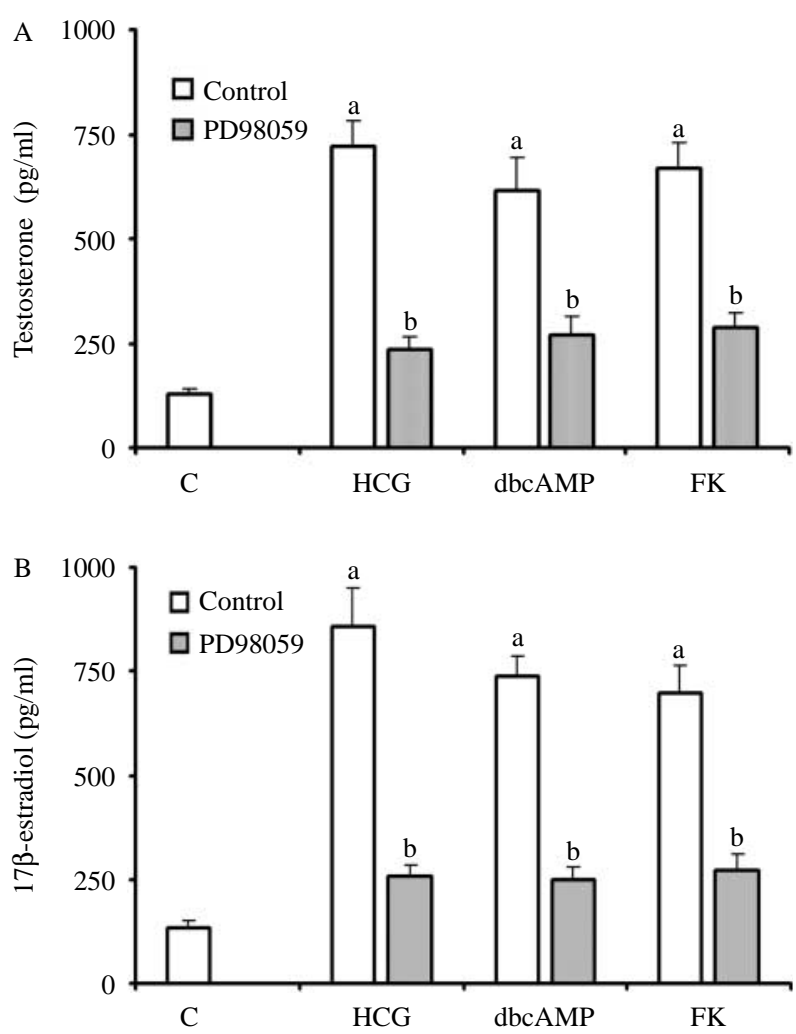

Figure 5 Effects of inhibitor of MEK1/2 on forskolin (FK)- and dbcAMP-stimulated steroid productions by co-incubated theca and granulosa cells (A and B). Cells were incubated in $500 \mu \mathrm{l}$ of serum-free DMEM for $16 \mathrm{~h}$ at $23 \pm 1^{\circ} \mathrm{C}$ containing HCG $(100 \mathrm{ng} / \mathrm{ml})$ and PD98059 $(1 \cdot 0 \mu \mathrm{M})$. Each value represents \pm S.E.M. of five experiments and comprises three replicate incubations of theca-granulosa cells obtained from single donor fish. ${ }^{a, b}$ Means with different letters differ significantly from each other $(P<0.05)$.

\section{Discussion}

In this paper, we demonstrate that calcium-mediated cell signaling is important in regulating gonadotropininduced testosterone and $\mathrm{E}_{2}$ production by short-term co-incubated theca and granulosa cells of C. carpio. Inhibition of steroid production in the presence of an L-type calcium channel blocker demonstrates that calcium influx from extracellular store is required for gonadotropin-stimulated steroidogenesis in ovarian follicles. Furthermore, inhibition of HCG-stimulated steroid production in the presence of a calmodulin inhibitor indicates that this calcium-binding protein is also involved in such processes. These results corroborate earlier findings with either whole ovarian follicles or isolated follicle cells of fish (Mukherjee et al. 2001, Benninghoff \& Thomas 2005, 2006a) and other vertebrates (Van Der Kraak \& Wade 1994). We further observed that addition of calcium ionophore A23187, which elevates intracellular calcium levels, was sufficient to increase steroid production by co-incubated follicle cells in the absence of gonadotropin. A similar stimulatory role of calcium ionophores on basal steroid production has also been reported in fish and other vertebrates (Srivastava \& Van Der Kraak 1994, Benninghoff \& Thomas 2005). The stimulatory effects of A23187 on HCG-induced testosterone and $\mathrm{E}_{2}$ production by cells of postvitellogenic ovarian follicles in our study further indicate a regulatory role of intracellular calcium in HCG-induced ovarian steroidogenesis in this species. Taken together, all these data indicate the involvement of calcium-dependent signaling in ovarian steroidogenesis in common carp.

Consistent with observations in other vertebrates and in fish (reviewed in Leung \& Steele (1992) and Benninghoff \& Thomas (2006a)), increased steroid production by co-incubated carp ovarian follicle cells in presence of FK and dbcAMP, the modulators of adenylate cyclase and PKA respectively, and inhibition of HCG-stimulated steroid production in the presence of a specific adenylate cyclase inhibitor, SQ22536, demonstrate the regulatory role of adenylate cyclase and PKA in gonadotropin-induced ovarian steroidogenesis in such fish. Although conflicting reports are available on the requirement of calcium ion in gonadotropin-stimulated cAMP production by rat and bovine granulosa cells (Tsang \& Carnegie 1984, Davis et al. 1987), reports with other mammals indicate that action of HCG to increase cAMP production requires the presence of calcium (Veldhuis \& Klase 1982, Asem \& Hertelendy 1986). The possible target for calcium is the adenylate cyclase, and increased intracellular calcium concentrations have both positive and negative effects on adenylate cyclase leading to increased and decreased production of cAMP (Jamaluddin et al. 1992, Srivastava \& Van Der Kraak 1994). Requirement of calcium ion in HCG-induced cAMP production by Atlantic croaker ovarian follicles has also been reported (Benninghoff \& Thomas 2006a).

Cross talk among various signal transduction systems, including adenylate cyclase- and calcium-dependent signaling pathways, has been demonstrated in many cell types and in response to a variety of receptor

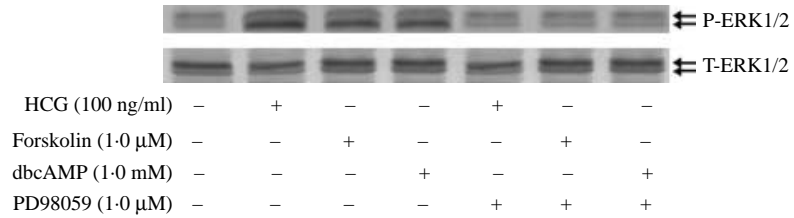

Figure 6 Effects of modulators of adenylate cyclase and PKA on ERK1/2 activation in co-incubated theca and granulosa cells. Immunoblot analyses of phosphorylated ERK1/2 (P-ERK1/2) and total ERK1/2 (T-ERK1/2) in cells incubated with $100 \mathrm{ng} / \mathrm{ml} \mathrm{HCG}$ or $1.0 \mu \mathrm{M}$ forskolin (FK) or $1.0 \mathrm{mM}$ dbcAMP with or without $1.0 \mu \mathrm{M}$ PD98059 for 120 min are shown. Immunoblot analyses were performed at least three times with nearly identical results. 


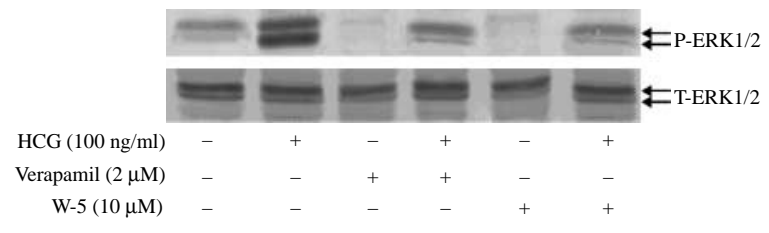

Figure 7 Effects of inhibitors of VSCCs and calmodulin on HCG-stimulated ERK $1 / 2$ phosphorylation in co-incubated theca and granulosa cells. Immunoblot analyses of phosphorylated ERK1/2 (P-ERK1/2) and total ERK1/2 (T-ERK1/2) in cells incubated with HCG $(100 \mathrm{ng} / \mathrm{ml})$ with or without either verapamil $(2 \mu \mathrm{M})$ or $\mathrm{W}-5(10 \mu \mathrm{M})$ for 120 min are shown. Immunoblot analyses were performed at least three times with nearly identical results.

agonists (Rasmussen 1981, Bygrave \& Roberts 1995, Richards 2001). In this study, we could not measure cAMP levels after HCG treatment, but increased basal and HCG-, as well as FK-, and dbcAMP-induced steroid productions in the presence of both extracellular and intracellular calcium may also suggest similar cross talk between adenylate cyclase/PKA and calcium in HCGinduced ovarian steroidogenesis in common carp.

Earlier studies both in fish and other vertebrates demonstrate a regulatory role of calcium and calmodulin distal to activation of adenylate cyclase and PKA (Kleis-San Francisco \& Schuetz 1988, Van Der Kraak 1991, Benninghoff \& Thomas 2006a). In this study, we also provide evidence for a regulatory role of calcium or calmodulin distal to activation of adenylate cyclase and PKA using inhibitors of VSCCs or calmodulin to block FK- and dbcAMP-stimulated steroid productions in the carp ovarian follicle cells. Requirement of active CaMK for full steroidogenic response to FK and dbcAMP in croaker ovarian follicle has also been demonstrated (Benninghoff \& Thomas 2006a). Thus, like other vertebrates, in common carp ovarian steroidogenesis, calcium and cAMP appear to act as dual second messenger molecules activating separate signaling pathways that may converge at a site distal to PKA activation.

The results of this study clearly show a third signaling pathway involving MEK1/2 and ERK1/2 in gonadotropin-induced steroidogenesis in common carp ovary. We observed that HCG treatment increased ERK1/2 phosphorylation in theca-granulosa cell lysate of common carp ovary almost in a dose- and timedependent manner. Involvement of the MAPK pathway in gonadotropin-induced ovarian steroidogenesis in fish has recently been demonstrated for the first time in Atlantic croaker by Benninghoff \& Thomas (2006b), and to our knowledge, demonstration of involvement of MAP kinase signaling in gonadotropin-stimulated steroidogenesis in common carp ovarian follicles may be the second one in any nonmammalian vertebrates. A role for MAPK/ERK signaling in regulating gonadotropin-induced steroidogenesis in mammalian and hen granulosa cells (Moore et al. 2001, Seger et al. 2001, Dewi et al. 2002, Cottom et al. 2003, Su et al. 2006, Woods $\&$ Johnson 2007) and also in rat Leydig cell (Martinelle et al. 2004) has been reported. Thus, fish being evolutionarily distant from mammal share a common signaling pathway in mediating gonadotropin-induced ovarian steroidogenesis.

We, in this study, further observed that HCGstimulated ERK1/2 phosphorylation leading to increased production of testosterone and $\mathrm{E}_{2}$ is significantly inhibited by an MEK1/2 inhibitor PD98059, suggesting that the action of HCG on ERK1/2 phosphorylation is mediated by the upstream MEK1/2. Similar effects of PD98059 and another MEK1/2 inhibitor, U-0126, on HCG-induced follicular cell steroidogenesis were observed in Atlantic croaker (Benninghoff \& Thomas 2006b). Although involvement of MAPK in mediating gonadotropin-stimulated steroidogenesis has been observed in many species, conflicting results in different steroidogenic tissues have been demonstrated (Seger et al. 2001, Dewi et al. 2002, Manna et al. 2002, 2006, Seto-Young et al. 2003, Martinelle et al. 2004, Tajima et al. 2005). For example, inhibition of MAPK/ERK1/2 activity with PD98059 and U0126 has been shown to be associated with stimulation (Seger et al. 2001, Tajima et al. 2003), inhibition (Gyles et al. 2001, Manna et al. 2002, Martinelle et al. 2004), or no effect (Tai et al. 2001, Seto-Young et al. 2003, Tajima et al. 2005) on steroidogenic response. Taken together, these findings demonstrate a complex role for the MAPK/ERK cascade in the regulation of the steroidogenic response that appeared to be tissue- and stimulus specific. The mechanism by which gonadotropin binding to its GPCRs triggers activation of the MEK/ERK pathway is still controversial. As suggested by previous workers (Pierce $e t$ al. 2001, Kim et al. 2002, Drube et al. 2006, Evaul \& Hammes 2008), it may be possible that gonadotropin binding to GPCRs in carp ovarian follicle cells activates the MEK/ERK pathway through trans-activation of EGFRs and further studies would require exploration of the actual mechanism of such trans-activation.

Involvement of cAMP in HCG-stimulated activation of ERK in carp ovarian follicle is demonstrated by showing increased ERK1/2 phosphorylation in presence of FK and dbcAMP. Similar cAMP-dependent ERK1/2 phosphorylation has been demonstrated in mammalian granulosa cells (Seger et al. 2001, Dewi et al. 2002, Cottom et al. 2003) and also in croaker ovarian follicles (Benninghoff \& Thomas 2006a). Attenuation of FK- and dbcAMP-stimulated ERK1/2 phosphorylations and steroid production by the MEK1/ 2 inhibitor PD98059 indicate that the function of the MEK/ERK pathway is likely to be distal to adenylate cyclase and PKA. As we have not used any PKA inhibitor in our study, involvement of PKA in HCG-stimulated ERK1/2 


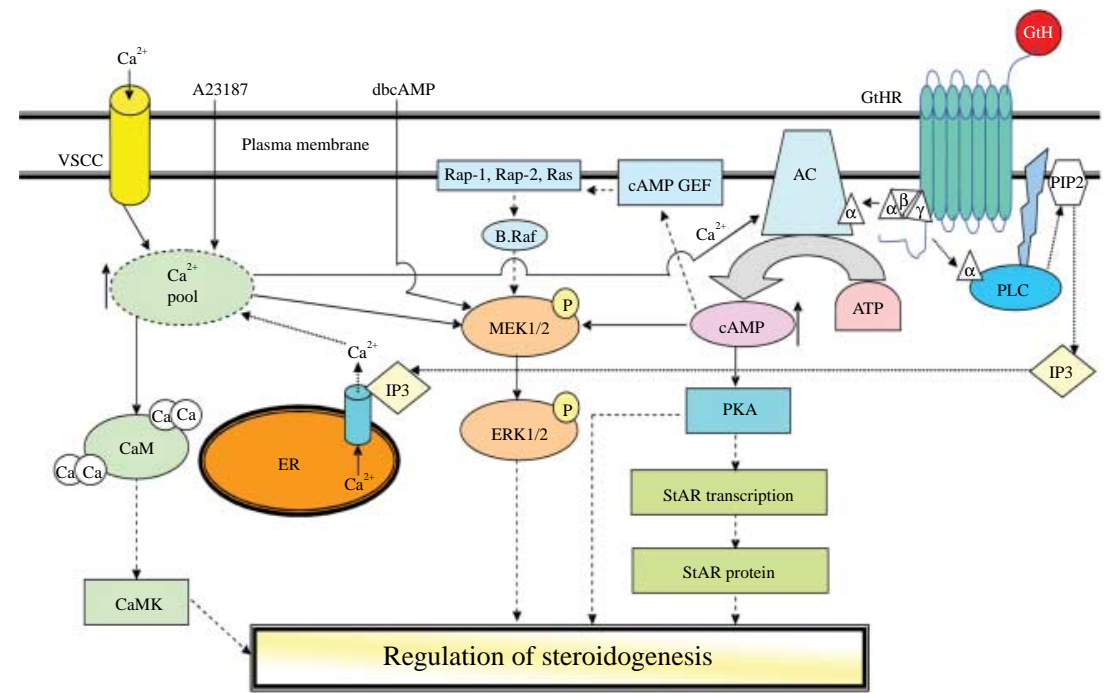

Figure 8 Model for signal transduction pathways regulating steroidogenesis in carp theca and granulosa cells. Gonadotropins (LH or HCG) activate GtHR, leading to increase in cAMP levels and subsequent PKA activity. Increase in PKA signaling regulates steroidogenesis. Calcium-dependent signaling pathways are also involved in the regulation of steroidogenesis. Increase in CAMP may also lead to the activation of MEK/ERK pathway independent of PKA through activation of cAMP-dependent guanine nucleotide exchange factor (cAMP-GEF). cAMP-GEF may in turn trigger small GTPases, such as Rap-1 and Rap-2, that are known to activate the MAP kinase cascade. Interactions among signaling pathways were observed as demonstrated by positive effects of elevated intracellular $\mathrm{Ca}^{2+}$ level on adenylate cyclase and the reduction of forskolin- or dbcAMP-mediated steroid production by inhibitors of VSCCs and calmodulin. Calcium-/calmodulin-dependent signaling pathways also appear to mediate gonadotropininduced ERK activation. Solid line indicates pathways investigated in this study. Dotted lines indicate pathways extensively studied in other vertebrate models. Dashed lines depict possible targets of regulation by these signaling pathways. AC, adenylate cyclase; CaM, calmodulin; CaMK, calcium-/calmodulin-dependent kinases; dbcAMP, dibutyryl cAMP; ER, endoplasmic reticulum; ERK, extracellular signal-regulated protein kinase; $\mathrm{GtH}$, gonadotropin; GtHR, gonadotropin receptor; IP3, inositol triphosphate; MEK, mitogen-activated protein kinase kinase; PIP2, phosphatidyl inositol 4,5-bisphosphate; PKA, cAMP-dependent protein kinase; PLC, phospholipase C; StAR, steroidogenic acute regulatory protein; VSCC, voltage-sensitive calcium channel. Full color version of this figure available via http://dx.doi.org/10.1677/JME-10-0061.

phosphorylation in this species is not clear. Earlier studies with croaker ovarian follicles suggested that the stimulatory effect of HCG on ERK phosphorylation is not mediated through PKA (Benninghoff \& Thomas $2006 a)$. On the contrary, involvement of PKA in gonadotropin-induced ERK activation has been demonstrated in rat and human granulosa cells (Seger et al. 2001, Dewi et al. 2002). One mechanism that activates the ERK cascade independent of PKA includes activation of cAMP-responsive guanosine nucleotide exchange factor for small GTPase such as Rap-1 and Rap-2. On binding with cAMP, these components rapidly activate Rap-1, which then promotes the activation of B-Raf and the rest of the ERK cascade (de Rooij et al. 1998, Richards 2001).

Some recent studies demonstrated a role for calcium, calmodulin, or CaMKs in the regulation of MAPK activity in a variety of cells (Agell et al. 2002,
Gomez et al. 2002, Stocco et al. 2002). Cottom et al. (2003) described that FSH induction of ERK activity in rat granulosa cells is mediated in part by calcium influx from extracellular stores and increases in cytosolic calcium induce ERK phosphorylation. In this study, clear inhibition of HCG-stimulated ERK1/2 phosphorylation in the presence of an antagonist of VSCCs and calmodulin indicates that HCG-induced ERK activity in such cells is likely to be mediated by calcium-dependent signal transduction. In Atlantic croaker ovarian follicles, however, HCG-induced ERK activity is not mediated by calcium-calmodulin-dependent signal transduction (Benninghoff \& Thomas 2006b). Thus, a novel role of calcium and calmodulin in the activation of the MAP kinase signaling cascade involving MEK1/2 and ERK1/2 in the regulation of gonadotropin-induced steroidogenesis has been identified for the first time in fish ovarian follicles. It is therefore 
possible that the major signaling pathway regulating steroidogenesis identified in this study including adenylate cyclase-, calcium-, and MAPK-dependent pathways converges at a point distal to activation of PKA and ERK1/2. The possible target for coordinate regulation of this signaling pathway may be the steroidogenic acute regulatory protein and/or transcription factor regulating its synthesis because there is evidence that in steroidogenic cells, cAMP, PKA, calcium, CaMK, and MAPK can modulate the activity of this protein or associated transcription factors (Cherradi et al. 1997, Manna et al. 1999, Gyles et al. 2001, Tajima et al. 2003, Evaul \& Hammes 2008).

The present result together with a previous finding demonstrating calcium-dependent regulation of testosterone production (Benninghoff \& Thomas $2006 b$ ) shows that multiple but independent signaling pathways are operative in gonadotropin-induced ovarian steroidogenesis in carp ovarian follicles. This is summarized in the model of Fig. 8. The role of MAP kinase signaling cascade involving MEK1 / 2 and ERK1/2 in the regulation of gonadotropin-induced steroid production by co-incubated theca and granulosa cells has been identified. Furthermore, a novel role of calcium and calmodulin in the activation of the MAP kinase signaling cascade involving MEK1/2 and ERK1/2 in the regulation of gonadotropin-induced steroidogenesis has also been identified and there is evidence for a cross talk between the adenylate cyclase, calcium/ calmodulin, and MAP kinase pathways in this process.

\section{Declaration of interest}

The authors declare that there is no conflict of interest that could be perceived as prejudicing the impartiality of the research reported.

\section{Funding}

This work is partly supported by grants from University of Kalyani, Kalyani, Nadia, India.

\section{Acknowledgements}

The authors are thankful to Prof. Samir Bhattacharya, Visva Bharati, Santiniketan, West Bengal, India for his constant inspiration; Dr Sib Sankar Roy, scientist, Indian Institute of Chemical Biology, Kolkata, West Bengal, India for donating SQ22536. The authors acknowledge Mr Swapan Mondal, laboratory technician, Indian Institute of Chemical Biology, Kolkata, West Bengal, India for his excellent technical assistance.

\section{References}

Agell N, Bachs O, Rocamora N \& Villalonga P 2002 Modulation of the Ras/Raf/MEK/ERK pathway by $\mathrm{Ca}^{2+}$, and calmodulin. Cellular Signalling 14 649-654. (doi:10.1016/S0898-6568(02)00007-4)
Amsterdam A, Tajima K, Frajese V \& Seger R 2003 Analysis of signal transduction stimulated by gonadotropins in granulosa cells. Molecular and Cellular Endocrinology 202 77-80. (doi:10.1016/S03037207(03)00066-2)

Asem EK \& Hertelendy F 1986 Influence of follicular maturation on luteinizing hormone, cyclic $3^{\prime}, 5^{\prime}$ adenosine monophosphateforskolin and cholesterol-stimulated progesterone production in hen granulosa cells. Biology of Reproduction 32 257-268. (doi:10.1095/biolreprod32.2.257)

Benninghoff AD \& Thomas P 2005 Involvement of calcium and calmodulin in the regulation of ovarian steroidogenesis in Atlantic croaker (Micropogonias undulatus) modulation by Aroclor 1254. General and Comparative Endocrinology 144 211-223. (doi:10.1016/ j.ygcen.2005.06.005)

Benninghoff AD \& Thomas P 2006 $a$ Gonadotropin regulation of testosterone production by primary cultured theca and granulosa cells of Atlantic croaker: I. Novel role of CaMKs and interactions between calcium- and adenylyl cyclase-dependent pathways. General and Comparative Endocrinology 147 276-287. (doi:10.1016/j.ygcen. 2006.01.014)

Benninghoff AD \& Thomas P 2006 $b$ Gonadotropin regulation of testosterone production by primary cultured theca and granulosa cells of Atlantic croaker: II. Involvement of a mitogen-activated protein kinase pathway. General and Comparative Endocrinology 147 288-296. (doi:10.1016/j.ygcen.2006.01.013)

Bygrave FL \& Roberts HR 1995 Regulation of cellular calcium through signaling cross-talk involves an intricate interplay between the actions receptors, G-proteins, and second messengers. FASEB Journal 9 1297-1303.

Cherradi N, Rossier MF, Valloton MB, Timberg R, Friedberg I, Orly J, Wang XJ, Stocco DM \& Capponi AM 1997 Submitochondrial distribution of three key steroidogenic proteins (steroidogenic acute regulatory protein and cytochrome P450scc and $3 \beta$-hydroxy steroid dehydrogenase isomerase enzymes) upon stimulation by intracellular calcium in adrenal glomerulosa cells. Journal of Biological Chemistry 272 7899-7907. (doi:10.1074/jbc. 272.12.7899)

Cottom J, Salvador LM, Maizels ET, Reierstad S, Park Y, Carr DW, Davare MA, Hell JW, Palmer SS, Dent P et al. 2003 Folliclestimulating hormone activates extracellular signal-regulated kinase but not extracellular signal-regulated kinase kinase through a $100-\mathrm{kDa}$ phosphotyrosine phosphatase. Journal of Biological Chemistry 278 7167-7179. (doi:10.1074/jbc. M203901200)

Davis JS, Weakland LL, Farese RV \& West LA 1987 Luteinizing hormone increases inositol trisphosphate and cytosolic free $\mathrm{Ca}^{2+}$ in isolated bovine luteal cells. Journal of Biological Chemistry 262 8515-8521.

Dewi DA, Abayasekara DRE \& Wheeler-Jones CPD 2002 Requirement for ERK1/2 activation in the regulation of progesterone production in human granulosa-lutein cells is stimulus specific. Endocrinology 143 877-888. (doi:10.1210/en.143.3.877)

Drube S, Stirnweiss J, Valkova C \& Liebmann C 2006 Ligandindependent and EGF receptor supported transactivation: lessons from $\beta_{2}$-adrenergic receptor signalling. Cellular Signalling 18 1633-1646. (doi:10.1016/j.cellsig.2006.01.003)

Evaul K \& Hammes SR 2008 Cross-talk between G protein-coupled and epidermal growth factor receptors regulates gonadotropinmediated steroidogenesis in Leydig cells. Journal of Biological Chemistry 283 27525-27533. (doi:10.1074/jbc.M803867200)

Gomez E, Pritchard C \& Herbert TP 2002 cAMP-dependent protein kinase and $\mathrm{Ca}^{2+}$ influx through L-type voltage-gated calcium channels mediate Raf-independent activation of extracellular regulated kinase in response to glucagon-like peptide-1 in pancreatic $\beta$ cells. Journal of Biological Chemistry 277 48146-48151. (doi:10.1074/jbc.M209165200)

Guillou JL, Nakata H \& Cooper DM 1999 Inhibition by calcium of mammalian adenylyl cyclases. Journal of Biological Chemistry 274 35539-35545. (doi:10.1074/jbc.274.50.35539) 
Gyles SL, Burnes CJ, Whitehouse BJ, Sugden D, Marsh P, Persaud SJ \& Jones PM 2001 ERKs regulate cyclic AMP-induced steroid synthesis through transcription of the steroidogenic acute regulatory (StAR) gene. Journal of Biological Chemistry 276 34888-34895. (doi:10.1074/ jbc.M102063200)

Jamaluddin M, Molnár M \& Hertelendy F 1992 Biphasic effect of calcium on luteinizing hormone-stimulated cyclic adenosine $3^{\prime}, 5^{\prime}$-monophosphate production in granulosa cells of the fowl (Gallus domesticus). Biology of Reproduction 46 698-704. (doi:10.1095/ biolreprod46.4.698)

Kim J, Eckhart AD, Eguchi S \& Koch WJ 2002 $\beta$-Adrenergic receptormediated DNA synthesis in cardiac fibroblasts is dependent on transactivation of the epidermal growth factor receptor and subsequent activation of extracellular signal-regulated kinases. Journal of Biological Chemistry 277 32116-32123. (doi:10.1074/jbc. M204895200)

Kleis-San Francisco S \& Schuetz AW 1988 Role of protein kinase C activation in oocyte maturation and steroidogenesis in ovarian follicles of Rana pipiens: studies with phorbol 12-myristate 13-acetate. Gamete Research 21 323-334. (doi:10.1002/mrd. 1120210313)

Leung PC \& Steele GL 1992 Intracellular signaling in the gonads. Endocrine Reviews 13 476-498. (doi:10.1210/edrv-13-3-476)

Lewis TS, Shapiro PS \& Ahn NG 1997 Signal transduction through MAP kinase cascades. Advances in Cancer Research 74 49-139. (doi:10.1016/S0065-230X(08)60765-4)

Lowry OH, Rosebrough NJ, Farr AE \& Randall RJ 1951 Protein measurement with Folin phenol reagent. Journal of Biological Chemistry 193 265-275.

Manna PR, Pakarinen P, El-Hefnawy T \& Huhtaniemi IT 1999 Functional assessment of the calcium messenger system in cultured mouse Leydig tumor cells: regulation of human chorionic gonadotropin-induced expression of the steroidogenic acute regulatory protein. Endocrinology 140 1739-1751. (doi:10.1210/ en.140.4.1739)

Manna PR, Huhtaniemi IT, Wang XJ, Eubank DW \& Stocco DM 2002 Mechanisms of epidermal growth factor signaling: regulation of steroid biosynthesis and the steroidogenic acute regulatory protein in mouse Leydig tumor cells. Biology of Reproduction 67 1393-1404. (doi:10.1095/biolreprod.102.007179)

Manna PR, Chandrala SP, Jo Y \& Stocco DM 2006 cAMP-independent signaling regulates steroidogenesis in mouse Leydig cells in the absence of StAR phosphorylation. Journal of Molecular Endocrinology 37 81-95. (doi:10.1677/jme.1.02065)

Martinelle N, Holst M, Soder O \& Svechnikov K 2004 Extracellular signal-regulated kinases are involved in the acute activation of steroidogenesis in immature rat Leydig cells by human chorionic gonadotropin. Endocrinology 145 4629-4634. (doi:10.1210/ en.2004-0496)

Moore RK, Otsuka F \& Shimasaki S 2001 Role of ERK1/2 in the differential synthesis of progesterone and estradiol synthesis by granulosa cells. Biochemical and Biophysical Research Communications 289 796-800. (doi:10.1006/bbrc.2001.6052)

Mukherjee D, Chakraborti P, Sen U \& Debnath S 2001 Steroid production in vitellogenic and postvitellogenic ovarian follicles of common carp Cyprinus carpio - modulation by calcium ionophore. Proceedings of the Zoological Society 54 1-13.

Mukherjee D, Mukherjee D, Sen U, Paul S \& Bhattacharyya SP 2006 In vitro effects of insulin-like growth factors and insulin on oocyte maturation and maturation-inducing steroid production in ovarian follicles of common carp, Cyprinus carpio. Comparative Biochemistry and Physiology. Part A, Molecular E Integrative Physiology 144 63-77. (doi:10.1016/j.cbpa.2006.01.012)

Paul S, Mukherjee D, Pramanick K, Kundu S, Bhattacharya SP \& Mukherjee D 2008 Stimulation of salmon calcitonin on secretion of $17 \beta$-estradiol by the ovarian follicles of common carp, Cyprinus carpio. Journal of Endocrinology 196 413-424. (doi:10.1677/ JOE-07-0188)
Paul S, Pramanick K, Kundu S, Bandyopadhyay A \& Mukherjee D 2009 Involvement of PI3 kinase and MAP kinase in IGF-I- and insulin-induced oocyte maturation in Cyprinus carpio. Molecular and Cellular Endocrinology 309 93-100. (doi:10.1016/j.mce.2009. 05.014)

Paul S, Pramanick K, Kundu S, Kumar D \& Mukherjee D 2010 Regulation of ovarian steroidogenesis in vitro by IGF-I and insulin in common carp, Cyprinus carpio: stimulation of aromatase activity and P450arom gene expression. Molecular and Cellular Endocrinology 315 95-103. (doi:10.1016/j.mce.2009.10.014)

Pierce KL, Luttrell LM \& Lefkowitz RJ 2001 New mechanisms in heptahelical receptor signaling to mitogen activated protein kinase cascades. Oncogene 20 1532-1539. (doi:10.1038/sj.onc.1204184)

Rasmussen H 1981. Calcium and cAMP as Synarchic Messengers, New York: John Wiley \& Sons.

Richards JS 2001 New signaling pathways for hormones and cyclic adenosine $3^{\prime}, 5^{\prime}$ monophosphate action in endocrine cells. Molecular Endocrinology 15 209-218. (doi:10.1210/me.15.2.209)

de Rooij J, Zwartkruis FJ, Verheijen MH, Cool RH, Nijman SM, Wittinghofer A \& Bos JL 1998 Epac is a Rapl guanine-nucleotideexchange factor directly activated by cyclic AMP. Nature 396 474-477. (doi:10.1038/24884)

Seger R \& Krebs EG 1995 The MAP kinase signaling cascade. FASEB Journal 9 726-735.

Seger R, Hanoch T, Rosenberg R, Dantes A, Merz WE, Strauss JF III \& Amsterdam A 2001 The ERK signaling cascades inhibits gonadotropin-stimulated steroidogenesis. Journal of Biological Chemistry 276 13957-13964. (doi:10.1074/jbc.M006852200)

Seto-Young D, Zajac J, Liu HC, Rosenwaks Z \& Poretsky L 2003 The role of mitogen-activated protein kinase in insulin and insulinlike growth factor I (IGF-I) signaling cascades for progesterone and IGF binding protein-1 production in human granulosa cells. Journal of Clinical Endocrinology and Metabolism 88 3385-3391. (doi:10.1210/jc.2002-021965)

Srivastava RK \& Van Der Kraak G 1994 Effects of activators of different intra-cellular signaling pathways on steroid production by goldfish vitellogenic ovarian follicles. General and Comparative Endocrinology 93 181-191. (doi:10.1006/gcen.1994.1021)

Stocco CO, Lau LF \& Gibori G 2002 A calcium/calmodulin-dependent activation of ERK1/2 mediates JunD phosphorylation and induction of nur 77 and $20 \alpha$-hsd genes by prostaglandin $\mathrm{F}_{2 \alpha}$ in ovarian cells. Journal of Biological Chemistry 277 3293-3302. (doi:10.1074/jbc.M110936200)

Su YQ, Nyegaard M, Overgaard MT, Qiao J \& Giudice LC 2006 Participation of mitogen-activated protein kinase in luteinizing hormone-induced differential regulation of steroidogenesis and steroidogenic gene expression in mural and cumulus granulosa cells of mouse preovulatory follicles. Biology of Reproduction $\mathbf{7 5}$ 859-867. (doi:10.1095/biolreprod.106.052613)

Tai CJ, Kang SK, Choi KC, Tzeng CR \& Leung PC 2001 Role of mitogen-activated protein kinase in prostaglandin $\mathrm{F}_{2 \alpha}$ action in human granulosa-luteal cells. Journal of Clinical Endocrinology and Metabolism 86 375-380. (doi:10.1210/jc.86.1.375)

Tajima K, Dantes A, Yao Z, Sorokina K, Kotsuji F, Seger R \& Amsterdam A 2003 Down-regulation of steroidogenic response to gonadotropins in human and rat pre-ovulatory granulosa cells involves mitogen-activated protein kinase activation and modulation of DAX-1 and steroidogenic factor-1. Journal of Clinical Endocrinology and Metabolism 88 2288-2299. (doi:10.1210/ jc. 2002-020913)

Tajima K, Yoshii K, Fukuda S, Orisaka M, Miyamoto K \& Amsterdam A 2005 Luteinizing hormone-induced extracellular signal regulated kinase activation differently modulates progesterone and androstenedione production in bovine theca cells. Endocrinology 146 2903-2910. (doi:10.1210/en.2005-0093)

Tsang BK \& Carnegie JA 1984 Calcium-dependent regulation of progesterone production by isolated rat granulosa cells: effects of 
the calcium ionophore $\mathrm{A} 23187$, prostaglandin $\mathrm{E}_{2}$, dl-isoproterenol and cholera toxin. Biology of Reproduction 30 787-794. (doi:10.1095/ biolreprod30.4.787)

Van Der Kraak G 1991 Role of calcium in the control of steroidogenesis in pre-ovulatory ovarian follicles of the goldfish. General and Comparative Endocrinology 81 268-275. (doi:10.1016/00166480(91)90011-T)

Van Der Kraak G \& Wade MG 1994 A comparison of signal transduction pathways mediating gonadotropin actions in vertebrates. In Perspectives in Comparative Endocrinology, pp 59-63. Eds KG Davey, SS Tobe \& RE Peter. Toronto, Canada: National Research Council of Canada.
Veldhuis JD \& Klase PA 1982 Mechanisms by which calcium ions regulate the steroidogenic actions of luteinizing hormone in isolated ovarian cells in vitro. Endocrinology 111 1-6. (doi:10.1210/ endo-111-1-1)

Woods DC \& Johnson AL 2007 Protein kinase C activity mediates LH-induced ErbB/Erk signaling in differentiated hen granulosa cells. Reproduction 133 733-741. (doi:10.1530/REP-06-0261)

Received in final form 7 July 2010

Accepted 28 July 2010

Made available online as an Accepted Preprint 28 July 2010 